\title{
RUBRIK NURSING CLINICAL EXERCISE: PENGEMBANGAN INSTRUMEN PENILAIAN KOMPETENSI KLINIS PADA PENDIDIKAN KLINIK KEPERAWATAN
}

\author{
Retno Sumiyarrini*, Gandes Retno Rahayu**, Yoyo Suhoyo** \\ *Mahasiswa S2 IImu Pendidikan Kedokteran, Fakultas Kedokteran Universitas Gadjah Mada, Yogyakarta - INDONESIA \\ ** Fakultas Kedokteran Universitas Gadjah Mada, Yogyakarta - INDONESIA
}

\begin{abstract}
Background: Clinical Skills is a fundamental ability that must be mastered by the newly graduated nurses. Therefore, assessment of clinical competence is essential to be considered by educators and education managers. It needs a valid assessment instrument, which is reliable and impactful on learning the process by giving a structured feedback so that qualified graduates can be produced. Some assessment instruments in the clinical nursing education have less evidence of validity and reliability and less feasible, so it requires a development of clinical assessment instruments. This study aims to develop a clinical assessment instrument in the nursing clinic and to test the content validity.

Method: This study used a qualitative research design that includes drafting through literature review and expert review by the expert panel.

Results: The process of drafting and reviewing produces a rubric named Nursing Clinical Exercise (NCEx) made of six domains consisting the assessment of subjective data, physical examination, diagnosis formulation, treatment planning formulation, communication and interpersonal relationships, and professionalism. The value of content validity is good (CVR of the entire domain $=1)$

Conclusion: The NCEx Rubric consists of six domains and has good content validity.
\end{abstract}

Keywords: mini-CEX, Nursing Clinical Exercise (NCEx), clinical competence of nurses, clinical assessment

\begin{abstract}
ABSTRAK
Latar belakang: Keterampilan klinis adalah kemampuan mendasar yang wajib dikuasai oleh perawat yang baru lulus. Oleh karena itu, penilaian kompetensi klinis merupakan hal yang penting untuk diperhatikan oleh pendidik dan pengelola pendidikan. Dibutuhkan instrument penilaian yang valid, reliabel dan memiliki dampak terhadap pembelajaran melalui pemberian feedback yang terstruktur sehingga lulusan yang dihasilkan berkualitas. Beberapa instrument penilaian di pendidikan klinik keperawatan kurang memberikan bukti validitas dan reliabilitas serta kurang fisibel, sehingga diperlukan pengembangan intrumen penilaian klinik. Penelitian ini bertujuan untuk mengembangkan instrument penilaian klinik di keperawatan dan melakukan uji content validity

Metode: Penelitian ini menggunakan desain penelitian kualitatif yang meliputi penyusunan draft melalui literature review dan proses review draft oleh expert melalui expert panel.

Hasil: Proses penyusunan dan review menghasilkan rubrik yang diberi nama Nursing Clinical Exercise (NCEx) yang terdiri dari 6 domain yakni pengkajian data subjektif, pemeriksaan fisik, perumusan diagnosa,
\end{abstract}

Contact: retno.sumiyarini@gmail.com 
perumusan perencanaan perawatan, komunikasi dan hubungan interpersonal, dan profesionalisme. Nilai content validity baik (CVR seluruh domain $=1$ )

Kesimpulan: Rubrik NCEx terdiri dari 6 domain dan memiliki konten validity yang baik.

Kata kunci: mini CEx, Nursing Clinical Exercise (NCEx), kompetensi klinis perawat, penilaian klinik

\section{PENDAHULUAN}

Keterampilan klinis adalah kemampuan mendasar yang wajib dikuasai oleh perawat yang baru lulus dan dimandatkan di dalam standar kompetensi perawat. ${ }^{1}$ Keterampilan klinis yang baik akan menjamin kualitas praktik keperawatan ${ }^{2}$ dan menjamin keselamatan pasien ${ }^{1,3,4}$ serta membuat perawatan pasien menjadi lebih efisien. ${ }^{5}$ Oleh karena itu, penilaian kompetensi klinis merupakan hal yang mendasar dan krusial bagi pendidik dan pengelola pendidikan. ${ }^{1}$ Tujuan penilaian adalah menghasilkan lulusan perawat yang mampu memberikan pelayanan secara aman, bekerja secara etis dan bertanggung jawab, ${ }^{1}$ sehingga dibutuhkan proses dan instrument penilaian yang valid, reliabel dan memiliki dampak terhadap pembelajaran melalui pemberian feedback yang terstruktur sehingga lulusan yang dihasilkan berkualitas.

Beberapa instrumen penilaian keterampilan klinis telah dikembangkan di pendidikan klinik keperawatan, diantaranya adalah DOPS,${ }^{4}$ handoff CEx. ${ }^{6}$ Structured Observation and Assessment of Practice (SOAP), dan metode penilaian yang lain. ${ }^{1}$ Berdasarkan sistematic review oleh $\mathrm{Wu}$ et $\mathrm{al}^{1}$ disimpulkan bahwa metode-metode tersebut lebih banyak menggunakan self-assessment mahasiswa dan belum mencantumkan bukti reliabilitas dan validitas, selain itu fisibilitasnya masih dipertanyakan karena memerlukan waktu yang panjang dalam satu kali penilaian. Dibandingkan dengan beberapa metode tersebut, instrumen penilaian keterampilan klinis yang dikembangkan di pendidikan klinik kedokteran, yakni mini CEX, dinilai lebih fisibel karena dapat dilakukan selama 25-35 menit ${ }^{7}$ atau $15-25$ menit dan memiliki dampak terhadap pembelajaran karena selalu diikuti dengan pemberian feedback. Namun demikian, metode skoring dalam mini CEX berupa rating scale dan belum terdapat deskriptor performa yang jelas. ${ }^{8}$ Hal ini membuat penguji tidak yakin dalam memberikan nilai. ${ }^{9,10}$ Ketidakyakinan akan mengakibatkan pemberian feedback yang kurang spesifik. Feedback yang kurang spesifik kurang mengarahkan mahasiswa untuk merencanakan improvement. ${ }^{3}$

Diperlukan pengembangan instrumen penilaian keterampilan klinis perawat yang memudahkan penguji dalam memberikan nilai karena adanya deskriptor yang jelas serta memiliki validitas dan reliabilitas yang baik. Deskriptor yang jelas akan memudahkan pemberian corrective feddback. ${ }^{9,11}$ Deskriptor dalam bentuk lembar penilaian rubrik memberikan gambaran mengenai kriteria yang diharapkan, memudahkan identifikasi area spesifik yang kurang dan harus di-improve, sehingga memudahkan pemberian feedback yang spesifik bagi peserta didik..$^{12-14}$ Pada akhirnya, feedback yang detail dan spesifik akan meningkatkan progres keterampilan di klinik. ${ }^{15-17}$

Untuk memastikan instrumen yang dikembangkan valid dan reliabel, dilakukan uji validitas dan reliabilitas. Terdapat beberapa macam validtas dan reliabilitas, namun dalam penelitian awal pengembangan instrumen ini dipilih validitas konten. Validasi instrumen dilakukan melalui review oleh expert panel untuk menentukan relevansi domain-domain yang disusun dalam rubrik apakah dengan domain penting yang harus dinilai dalam kompetensi klinis perawat.

Penelitian ini bertujuan untuk mengembangkan instrumen penilaian keterampilan klinis perawat dan melakukan uji validitas konten terhadap instrument yang dikembangkan serta mengetahui persepsi mahasiswa dan penguji terhadap instrument yang dikembangkan. 


\section{METODE}

Penelitian ini menggunakan pendekatan desain penelitian kuantitatif dan kualitatif yang bertujuan untuk mengembangkan instrumen penilaian kompetensi klinis perawat yang mengacu pada mini CEx yang dikembangkan oleh Norcini ${ }^{7}$ yang diberi nama Nursing Clinical Exercise (NCEx) dan melihat validity, interrater reliability, acceptability dan educational impact instrumen NCEx. Penelitian ini terdiri dari beberapa tahap yakni:

1. Penyusunan draft area/domain kompetensi klinis yang akan dinilai dalam lembar NCEx berdasarkan standar kompetensi klinis yang berasal dari nursing body beberapa negara dan artikel penelitian mengenai kompetensi klinis yang penting bagi perawat.

2. Menyusun deskriptor rubrik NCEx berdasarkan text book fundamental of nursing dan berkonsultasi dengan pembimbing sebagai expert dalam bidang assessment pendidikan.

3. Melakukan review draft rubrik yang telah disusun dengan mengundang 7 orang expert keperawatan yang berpengalaman di klinik maupun di pendidikan dalam sebuah workshop yang difasilitasi oleh pembimbing sebagai expert dalam dalam bidang assessment pendidikan. Draft ini dikoreksi dan diberi masukan kemudian direvisi untuk kemudian dikonsultasikan kembali sampai sesuai dengan masukan para expert.

4. Setelah proses revisi selesai, dilakukan uji content validity dengan mengukur kesepakatan para expert (Content Validity Index (CVI)). bahwa keseluruhan domain dan deskriptor yang tercantum dalam rubrik sudah relevan dengan apa yang seharusnya diukur.

5. Melakukan uji coba insrumen dan melihat persepsi mahasiswa dan penguji mengenai instrument NCEx.

Analisis content validity adalah dengan menghitung nilai Content Validity Index..$^{18}$ Analisis inter rater dengan menghitung nilai alfa cronbach. Analisis persepsi mahasiswa dan dosen dengan distribusi frekuensi.

\section{HASIL DAN PEMBAHASAN}

\section{Draft domain kompetensi dan deskriptor rubrik NCEx}

Untuk memastikan lembar rubrik NCEx secara konten mencerminkan domain penting yang harus dinilai dari kompetensi keperawatan, maka proses penyusunan instrumen dimulai dengan pembuatan blue print instrumen melalui proses literature review. Rubrik dibuat dengan menentukan domain kompetensi, item dari masing-masing domain beserta deskriptor yang akan dinilai yang mencerminkan standar kompetensi perawat. Domain ini ditentukan berdasarkan standar kompetensi perawat dari beberapa negara dan penelitian survey mengenai aspek yang penting untuk dikuasai perawat di klinik. Setelah domain ditetapkan, berikutnya adalah menentukan deskriptor untuk masing-masing domain berdasarkan literatur keperawatan. 


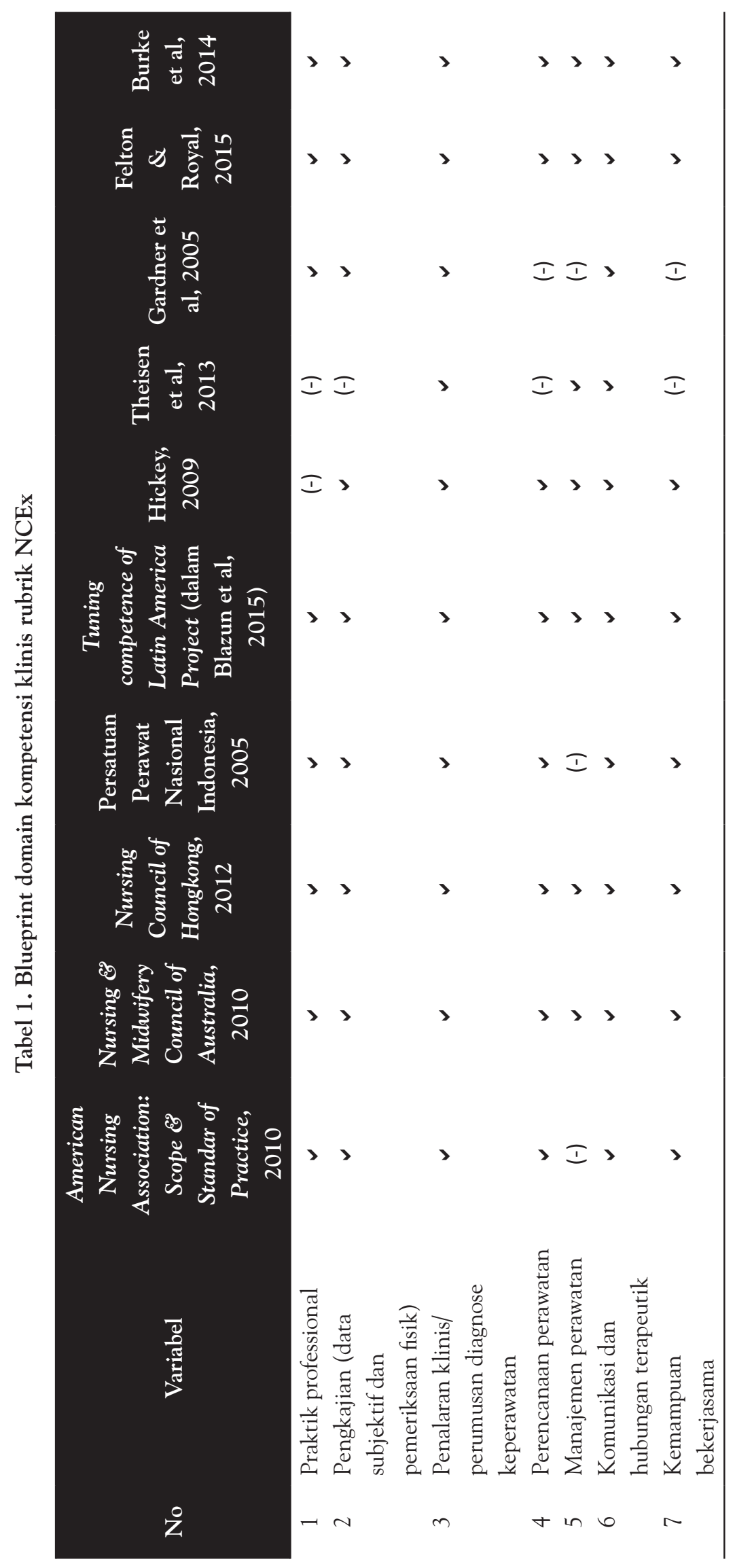


Tabel 2. Blueprint deskriptor rubrik NCEx

\begin{tabular}{|c|c|c|c|c|}
\hline No & Domain & Item & Deskriptor & Referensi \\
\hline \multirow{4}{*}{1.} & \multirow{4}{*}{$\begin{array}{l}\text { Pengkajian data } \\
\text { subjektif }\end{array}$} & $\begin{array}{l}\text { Sistematika proses } \\
\text { pengkajian }\end{array}$ & $\begin{array}{l}\text { Persiapan, orientasi, tahap } \\
\text { kerja }\end{array}$ & $\begin{array}{l}\text { (ANA, 2010; Nursing } 8 \\
\text { Midwifery Board of Australia, } \\
\text { 2006; Potter \& Perry, 2009) }\end{array}$ \\
\hline & & Pengkajian data fokus & $\begin{array}{l}\text { - Mengkaji masalah utama } \\
\text { pasien } \\
\text { - Mengeksplore masalah } \\
\text { utama }\end{array}$ & $\begin{array}{l}\text { (Llyod \& Craig, 2007; Potter } \\
\text { \& Perry, 2009; Essenberg et } \\
\text { al, 2015; Taylor et al, 2011) }\end{array}$ \\
\hline & & $\begin{array}{l}\text { Mampu menentukan } \\
\text { pola fungsi tubuh yang } \\
\text { terganggu }\end{array}$ & $\begin{array}{l}\text { Menentukan pola fungsi tubuh } \\
\text { berdasarkan masalah utama } \\
\text { yang disampaikan }\end{array}$ & $\begin{array}{l}\text { (Potter \& Perry, 2009, } \\
\text { Brunner, 2010, Taylor, 2011) }\end{array}$ \\
\hline & & $\begin{array}{l}\text { Menggunakan format } \\
\text { terstandar }\end{array}$ & $\begin{array}{l}\text { Mengkaji masalah utama } \\
\text { secara sistematis berdasarkan } \\
\text { pola Gordon }\end{array}$ & $\begin{array}{l}\text { (ANA, 2010; Nursing Eु } \\
\text { Midwifery Board of Australia, } \\
\text { 2006; Potter \& Perry, 2009; } \\
\text { PPNI, 2005) }\end{array}$ \\
\hline \multirow{3}{*}{2.} & \multirow{3}{*}{ Pemeriksaan fisik } & $\begin{array}{l}\text { Persiapan (diri, } \\
\text { lingkungan, } \\
\text { peralatan) }\end{array}$ & $\begin{array}{l}\text { - Persiapan diri : Mencuci } \\
\text { tangan, memakai sarung } \\
\text { tangan } \\
\text { - Persiapan lingkungan : } \\
\text { Mengatur pencahayaan, } \\
\text { dan posisi pasien } \\
\text { - Mempersiapakan alat }\end{array}$ & $\begin{array}{l}\text { (Potter \& Perry, 2009; } \\
\text { Taylor, 2011) }\end{array}$ \\
\hline & & $\begin{array}{l}\text { Sistematika dan fokus } \\
\text { pemeriksaan }\end{array}$ & $\begin{array}{l}\text { - Dimulai dengan observasi } \\
\text { kodisi umum } \\
\text { - Berfokus pada area yang } \\
\text { relevan dengan keluhan } \\
\text { utama } \\
\text { - Pemeriksaan sistematis } \\
\text { berdasarkan format } \\
\text { pengkajian sistem tubuh } \\
\end{array}$ & $\begin{array}{l}\text { (Potter \& Perry, 2009; } \\
\text { Brunner, 2010; ANA, 2010; } \\
\text { Nursing } \mathcal{E} \text { Midwifery Board of } \\
\text { Australia, 2006) }\end{array}$ \\
\hline & & Teknik pemeriksaan & $\begin{array}{l}\text { Ketepatan dan keterampilan } \\
\text { penggunaan teknik } \\
\text { pemeriksaan fisik }\end{array}$ & $\begin{array}{l}\text { (Potter \& Perry, 2009; } \\
\text { Brunner, 2010; Taylo et al, } \\
\text { 2011) }\end{array}$ \\
\hline & \multirow{3}{*}{$\begin{array}{l}\text { Diagnosa } \\
\text { keperawatan }\end{array}$} & $\begin{array}{l}\text { Kemampuan } \\
\text { interpretasi }\end{array}$ & $\begin{array}{l}\text { Interpretasi didasarkan pada } \\
\text { pemahaman anatomi, fisiologi, } \\
\text { biokimia tubuh manusia dan } \\
\text { pemeriksaan diagnostik yang } \\
\text { terstandar }\end{array}$ & $\begin{array}{l}\text { (Lasaster, 2006; Gardner, } \\
\text { 2005; Nursing } 8 \text { Midwifery } \\
\text { Board of Australia, 2006; } \\
\text { Potter \& Perry, 2009) }\end{array}$ \\
\hline & & Pemilihan diagnosa & $\begin{array}{l}\text { Secara kritis mampu } \\
\text { memutuskan diagnosa yang } \\
\text { paling sesuai berdasarkan } \\
\text { ketepatan interpretasi data dan } \\
\text { ketepatan mengidentifikasi } \\
\text { batasan karakteristik } \\
\end{array}$ & (Potter \& Perry, 2009) \\
\hline & & $\begin{array}{l}\text { Format analisa } \\
\text { data dan diagnosa } \\
\text { sesuai dengan sistem } \\
\text { klasifikasi }\end{array}$ & $\begin{array}{l}\text { Menuliskan diagnose } \\
\text { keperawatan terdiri dari: } \\
\text { pernyataan masalah, faktor } \\
\text { yang berhubungan dan data } \\
\text { batasan karakteristik }\end{array}$ & $\begin{array}{l}\text { (ANA, 2010; Nursing Eु } \\
\text { Midwifery Board of Australia, } \\
\text { 2006; De Laune \& Lardner, } \\
\text { 2002) }\end{array}$ \\
\hline
\end{tabular}




\begin{tabular}{|c|c|c|c|c|}
\hline \multirow[t]{2}{*}{4.} & \multirow{2}{*}{$\begin{array}{l}\text { Perencanaan } \\
\text { perawatan }\end{array}$} & Penetapan tujuan & $\begin{array}{l}\text { Kriteria tujuan mengarah } \\
\text { pada batasan karakteristik } \\
\text { diagnosa dan SMART } \\
\text { (Specific/spesifik, } \\
\text { measurable/dapat diukur, } \\
\text { Attainable/dapat dicapai, } \\
\text { Rational/rasional, Time/ada } \\
\text { batasan waktu pencapaian). } \\
\text { - Pemilihan tujuan } \\
\text { mempertimbangkan } \\
\text { karakteristik pasien, } \\
\text { ketersediaan sumber } \\
\text { pendukung } \\
\end{array}$ & $\begin{array}{l}\text { (ANA, 2010; Nursing } \mathcal{E} \\
\text { Midwifery Board of Australia, } \\
\text { 2006; Taylor et al, 2011; } \\
\text { NOC, 2013; Taylor et al } \\
\text { 2011, Potter \& Perry, 2009, } \\
\text { Cox, 2007) }\end{array}$ \\
\hline & & Rencana tindakan & $\begin{array}{l}\text { - Rencana tindakan mengacu } \\
\text { pada etiologi diagnosa } \\
\text { - Memilih tindakan } \\
\text { berdasarkan eviden yang } \\
\text { ilmiah } \\
\text { - Mampu mengidentifikasi } \\
\text { tindakan yang terdiri dari } \\
\text { aktivitas mandiri, tindakan } \\
\text { delegasi dokter dan } \\
\text { kolaborasi } \\
\text { - Menjelaskan rasionalisasi } \\
\text { tindakan }\end{array}$ & $\begin{array}{l}\text { (ANA, 2010; Nursing } \mathcal{E} \\
\text { Midwifery Board of Australia, } \\
\text { 2006; Taylor et al, 2011; } \\
\text { NOC, 2013; Taylor et al } \\
\text { 2011, Potter \& Perry, 2009, } \\
\text { Cox, 2007) }\end{array}$ \\
\hline & $\begin{array}{l}\text { Manajemen } \\
\text { tindakan }\end{array}$ & $\begin{array}{l}\text { Efisiensi waktu, } \\
\text { peralatan dan mampu } \\
\text { mengidentitifkasi } \\
\text { kekurangan diri }\end{array}$ & $\begin{array}{l}\text { Efisiensi waktu, peralatan dan } \\
\text { mampu mengidentitifkasi } \\
\text { kekurangan diri }\end{array}$ & $\begin{array}{l}\text { (Potter\& Perry, 2009; } \\
\text { Hickey, 2009) }\end{array}$ \\
\hline & \multirow{2}{*}{$\begin{array}{l}\text { Komunikasi } \\
\text { dan hubungan } \\
\text { interpersonal }\end{array}$} & $\begin{array}{l}\text { Teknik komunikasi } \\
\text { verbal }\end{array}$ & $\begin{array}{l}\text { Penggunaan bahasa, jeda dan } \\
\text { klarifikasi }\end{array}$ & $\begin{array}{l}\text { (Potter \& Perry, 2009; Taylor } \\
\text { et al, 2011) }\end{array}$ \\
\hline & & $\begin{array}{l}\text { Teknik komunikasi } \\
\text { non verbal }\end{array}$ & $\begin{array}{l}\text { Ekspresi, gestur dan kontak } \\
\text { mata }\end{array}$ & \\
\hline & Profesionalisme & $\begin{array}{l}\text { Penerapan nilai } \\
\text { profesional }\end{array}$ & $\begin{array}{l}\text { Empati, menghargai pasien, } \\
\text { meenerapkan batas-batas } \\
\text { personal sesuai nilai dan } \\
\text { budaya pasien }\end{array}$ & $\begin{array}{l}\text { (ANA, 2010; Nursing Eु } \\
\text { Midwifery Board of Australia, } \\
\text { 2006; PPNI, 2005; Felton \& } \\
\text { Royal, 2014; Ossenberg et al, } \\
\text { 2015) }\end{array}$ \\
\hline
\end{tabular}

\section{Rubrik NCEx hasil review oleh expert}

Setelah proses penyusunan draft dan berkonsultasi dengan pembimbing, proses selanjutnya adalah proses review melalui diskusi panel oleh expert. Expert adalah dosen keperawatan dengan latar pendidikan S3 dan perawat klinik dengan latar belakang pendidikan minimal S2 di bidang keperawatan/kesehatan. Proses diskusi dilaksanakan selama satu hari hingga tercapai kesepakatan mengenai domain dan deskriptor dalam lembar penilaian NCex. Setelah melalui proses review, dihasilkan rubrik NCEx berikut ini: 
Tabel 3. Rubrik NCEx hasil review expert

Nama

NIM

Setting Ruangan

Diagnosa medis

Posisi penguji

Bangsal

$\square$ Poliklinik

$\square$ lain-lain

Jumlah NCEX sebelumnya

$\square$ Pembimbing klinik

Dosen akademik

Berilah tanda centang pada kotak kecil di pojok kanan bawah masing-masing variabel

\begin{tabular}{|c|c|c|c|c|}
\hline Variabel & Item & $\begin{array}{c}\text { Di atas harapan } \\
\text { (2) }\end{array}$ & $\begin{array}{c}\text { Sesuai harapan } \\
\text { (1) }\end{array}$ & $\begin{array}{c}\text { Tidak sesuai harapan } \\
(0)\end{array}$ \\
\hline \multirow{4}{*}{$\begin{array}{l}\text { Pengkajian } \\
\text { fokus data } \\
\text { subjektif }\end{array}$} & $\begin{array}{l}\text { Tahap persiapan } \\
\text { dan orientasi }\end{array}$ & $\begin{array}{l}\text { - Membaca dan } \\
\text { memahami status } \\
\text { pasien } \\
\text { - Memperkenalkan diri } \\
\text { - Menjelaskan tujuan } \\
\text { - Kontrak dg pasien } \\
\text { (tujuan, waktu, topic) } \\
\text { - Percaya diri }\end{array}$ & $\begin{array}{l}\text { - Membaca status } \\
\text { pasien } \\
\text { - Memperkenalkan diri } \\
\text { - Menjelaskan tujuan } \\
\text { - Kurang percaya diri }\end{array}$ & $\begin{array}{l}\text { Melakukan } 2 \\
\text { dari } 3 \text { aspek } \\
\text { (membaca status, } \\
\text { memperkenalkan diri, } \\
\text { menjelaskan tujuan) }\end{array}$ \\
\hline & $\begin{array}{l}\text { Pengkajian } \\
\text { masalah utama }\end{array}$ & $\begin{array}{l}\text { - Menanyakan masalah } \\
\text { utama dan data yang } \\
\text { relevan secara lengkap: } \\
\text { - Onset, durasi } \\
\text { - Area tubuh dan } \\
\text { psikososial } \\
\text { - Faktor yang } \\
\text { memperparah atau } \\
\text { meredakan } \\
\end{array}$ & $\begin{array}{l}\text { Menanyakan masalah } \\
\text { utama dan } 2 \text { data yang } \\
\text { relevan }\end{array}$ & $\begin{array}{l}\text { Hanya menanyakan } \\
\text { masalah utama }\end{array}$ \\
\hline & $\begin{array}{l}\text { Interview } \\
\text { data terkait } \\
\text { gangguan } \\
\text { pemenuhan } \\
\text { kebutuhan }\end{array}$ & $\begin{array}{l}\text { - } \text { Menanyakan }>80 \% \\
\text { data terkait gangguan } \\
\text { pemenuhan kebutuhan } \\
\text { - Menggunakan format } \\
\text { Gordon/format } \\
\text { pengkajian system }\end{array}$ & $\begin{array}{l}\text { - Menanyakan < } \\
\text { 80\% data terkait } \\
\text { gangguan pemenuhan } \\
\text { kebutuhan } \\
\text { - Menggunakan format } \\
\text { Gordon/ format } \\
\text { pengkajian system }\end{array}$ & $\begin{array}{l}\text { Data yang dieksplor } \\
\text { tidak mengarah } \\
\text { kepada pemenuhan } \\
\text { kebutuhan pasien/ } \\
\text { system }\end{array}$ \\
\hline & $\begin{array}{l}\text { Penentuan pola } \\
\text { fungsi Gordon } \\
\text { yang terganggu }\end{array}$ & $\begin{array}{l}\text { - Menentukan implikasi } \\
\text { masalah utama } \\
\text { terhadap beberapa } \\
\text { pola fungsi Gordon } \\
\text { - Membuat skema/ } \\
\text { pathway }\end{array}$ & $\begin{array}{l}\text { Implikasi masalah pada } \\
\text { satu pola fungsi tubuh } \\
\text { yang terganggu }\end{array}$ & $\begin{array}{l}\text { Tidak mampu } \\
\text { menentukan pola } \\
\text { fungsi tubuh yang } \\
\text { terganggu }\end{array}$ \\
\hline $\begin{array}{l}\text { Pengkajian } \\
\text { fokus } \\
\text { pemeriksaan } \\
\text { fisik }\end{array}$ & $\begin{array}{l}\text { Persiapan } \\
\text { pemeriksaan } \\
\text { fisik }\end{array}$ & $\begin{array}{l}\text { - Seluruh persiapan } \\
\text { dilakukan: } \\
\text { - Mencuci tangan } \\
\text { dan memakai sarung } \\
\text { tangan } \\
\text { - Mengatur } \\
\text { pencahayaan dan } \\
\text { posisi pasien } \\
\text { - Mempersiapkan alat }\end{array}$ & $\begin{array}{l}\text { Melakukan } 2 \text { dari total } \\
3 \text { persiapan }\end{array}$ & $\begin{array}{l}\text { Hanya melakukan } 1 \\
\text { persiapan }\end{array}$ \\
\hline
\end{tabular}




\begin{tabular}{|c|c|c|c|c|}
\hline & $\begin{array}{l}\text { Sistematika } \\
\text { dan fokus } \\
\text { pemeriksaan } \\
\text { fisik }\end{array}$ & $\begin{array}{l}\text { - Dimulai observasi } \\
\text { kondisi umum } \\
\text { - Fokus: area yang } \\
\text { berhubungan dengan } \\
\text { masalah utama } \\
\text { - Pemeriksaaan urut }\end{array}$ & $\begin{array}{l}\text { - Dimulai observasi } \\
\text { kondisi umum } \\
\text { - Fokus: pada area yang } \\
\text { berhubungan dengan } \\
\text { masalah utama } \\
\text { - Pemeriksaan acak }\end{array}$ & $\begin{array}{l}\text { - Dimulai observasi } \\
\text { kondisi umum } \\
\text { - } \frac{\text { Gagal menentukan }}{\text { fokus area yang }} \\
\text { diperiksa } \\
\text { - Pemeriksaan acak }\end{array}$ \\
\hline & $\begin{array}{l}\text { Teknik } \\
\text { pemeriksaan }\end{array}$ & $\begin{array}{l}\text { - Prosedur benar dan } \\
\text { terampil } \\
\text { - Penggunaan alat tepat }\end{array}$ & $\begin{array}{l}\text { - Prosedur benar namun } \\
\text { kurang terampil } \\
\text { - Penggunaan alat tepat }\end{array}$ & $\begin{array}{l}\text { - Prosedur tidak } \\
\text { benar } \\
\text { - Penggunaan alat } \\
\text { tidak tepat }\end{array}$ \\
\hline \multirow{3}{*}{$\begin{array}{l}\text { Perumusan } \\
\text { diagnosa } \\
\text { keperawatan }\end{array}$} & $\begin{array}{l}\text { Kemampuan } \\
\text { interpretasi dan } \\
\text { pemahaman } \\
\text { ilmu biomedik } \\
\text { dasar }\end{array}$ & $\begin{array}{l}\text { Menginterpretasi } \\
\text { data berdasarkan } \\
\text { pemahaman } \\
\text { komprehensif ilmu } \\
\text { biomedik dasar } \\
\text { (Anatomi dan } \\
\text { fisiologi, Biokimia, } \\
\text { Patofisiologi) } \\
\end{array}$ & $\begin{array}{l}\text { - Mampu } \\
\text { menginterpretasi data } \\
\text { - } \underline{\text { Pemahaman ilmu }} \\
\underline{\text { biomedik dasar masih }} \\
\underline{\text { kurang }}\end{array}$ & $\begin{array}{l}\text { Kesulitan } \\
\text { mengintrepretasi data }\end{array}$ \\
\hline & $\begin{array}{l}\text { Pemilihan } \\
\text { diagnosa dan } \\
\text { pengelompokan } \\
\text { data }\end{array}$ & $\begin{array}{l}\text { - Mengelompokan data } \\
\text { berdasarkan batasan } \\
\text { karakteristik diagnosa } \\
\text { - Penentuan diagnosa } \\
\text { tepat } \\
\text { - Membedakan } \\
\text { diagnosa yg mirip } \\
\text { secara rasional }\end{array}$ & $\begin{array}{l}\text { - Mengelompokan data } \\
\text { berdasarkan batasan } \\
\text { karakteristik diagnosa } \\
\text { - Penentuan diagnosa } \\
\text { tepat } \\
\text { - Belum mampu } \\
\text { membedakan } \\
\text { diagnosa yg mirip } \\
\text { secara rasional }\end{array}$ & $\begin{array}{l}\text { - Pengelompokan } \\
\text { data berantakan } \\
\text { - Penetapan diagnosa } \\
\text { tidak tepat }\end{array}$ \\
\hline & $\begin{array}{l}\text { Format sesuai } \\
\text { dengan standar }\end{array}$ & $\begin{array}{l}\text { - Rumusan diagnosa } \\
\text { terdiri dari masalah, } \\
\text { tanda gejala } \\
\text { Penulisan dan } \\
\text { isi sesuai dengan } \\
\text { NANDA } \\
\end{array}$ & $\begin{array}{l}\text { - Rumusan diagnosa } \\
\text { terdiri dari masalah } \\
\text { dan tanda gejala } \\
\text { - } \underline{\text { Penulisan tidak }} \\
\underline{\text { sesuai dengan }} \\
\underline{\text { NANDA }}\end{array}$ & $\begin{array}{l}\text { Rumusan diagnosa } \\
\text { salah }\end{array}$ \\
\hline \multirow[b]{2}{*}{$\begin{array}{l}\text { Perencanaan } \\
\text { perawatan }\end{array}$} & $\begin{array}{l}\text { Menetapkan } \\
\text { tujuan }\end{array}$ & $\begin{array}{l}\text { - Kriteria tujuan } \\
\text { memenuhi } 3 \text { aspek: } \\
\text { - Indikator berdasar } \\
\text { batasan karakteristik } \\
\text { diagnosa } \\
\text { - Mengacu pada NOC } \\
\text { - SMART }\end{array}$ & $\begin{array}{l}\text { Kriteria tujuan } \\
\text { memenuhi } 2 \text { aspek. }\end{array}$ & $\begin{array}{l}\text { - Kriteria tujuan } \\
\text { - Tidak mengarah } \\
\text { pada batasan } \\
\text { karakteristik } \\
\text { diagnose } \\
\text { - Tidak berdasarkan } \\
\text { referensi }\end{array}$ \\
\hline & $\begin{array}{l}\text { Rencana } \\
\text { tindakan }\end{array}$ & $\begin{array}{l}\text { - Memilih tindakan } \\
\text { beradasar NIC } \\
\text { dan mengacu pada } \\
\text { diagnosa } \\
\text { - Menetapkan tindakan } \\
\text { mandiri, monitoring, } \\
\text { kolaborasi dan } \\
\text { pendidikan kesehatan } \\
\text { - Menentukan priorotas } \\
\text { tindakan }\end{array}$ & $\begin{array}{l}\text { - Memilih tindakan } \\
\text { beradasar NIC } \\
\text { dan mengacu pada } \\
\text { diagnosa } \\
\text { - Belum menginisiasi } \\
\text { tindakan mandiri }\end{array}$ & $\begin{array}{l}\text { Tindakan berdasarkan } \\
\text { kebiasaan yang ada }\end{array}$ \\
\hline
\end{tabular}




\begin{tabular}{|c|c|c|c|c|}
\hline \multirow[t]{2}{*}{$\begin{array}{l}\text { Komunikasi } \\
\text { dan hubungan } \\
\text { interpersonal }\end{array}$} & $\begin{array}{l}\text { Komunikasi } \\
\text { verbal }\end{array}$ & $\begin{array}{l}\text { - } \text { Bahasa dipahami } \\
\text { pasien } \\
\text { - Penggunaan istilah } \\
\text { yang mudah dipahami } \\
\text { - Menggunakan } \\
\text { jeda dan klarifikasi } \\
\text { interminten } \\
\end{array}$ & $\begin{array}{l}\text { - Bahasa dipahami } \\
\text { pasien } \\
\text { - Banyak penggunaan } \\
\text { istilah medis } \\
\text { - Menggunakan jeda }\end{array}$ & $\begin{array}{l}\text { - Pesan tidak dapat } \\
\text { ditangkap } \\
\text { - Komunikasi satu } \\
\text { arah }\end{array}$ \\
\hline & $\begin{array}{l}\text { Komunikasi } \\
\text { non verbal }\end{array}$ & $\begin{array}{l}\text { - Gestur dan kontak } \\
\text { mata proporsional } \\
\text { - Ekspresi hangat }\end{array}$ & $\begin{array}{l}\text { - Gestur dan kontak } \\
\text { mata proporsional } \\
\text { - Ekspresi tidak hangat }\end{array}$ & $\begin{array}{l}\text { - Tidak ada kontak } \\
\text { mata, gestur } \\
\text { menarik diri } \\
\text { - Ekspresi datar }\end{array}$ \\
\hline Profesionalisme & $\begin{array}{l}\text { Penerapan } \\
\text { nilai-nilai } \\
\text { profesional }\end{array}$ & $\begin{array}{l}\text { - Empati, menghargai } \\
\text { privasi } \\
\text { - Menghargai hak } \\
\text { pasien menentukan } \\
\text { pilihan } \\
\text { - Menetapkan batas- } \\
\text { batas personal sesuai } \\
\text { dengan nilai dan } \\
\text { budaya pasien }\end{array}$ & $\begin{array}{l}\text { - Empati, menghargai } \\
\text { privasi } \\
\text { - Menghargai hak } \\
\text { pasien menentukan } \\
\text { pilihan } \\
\text { - Tidak menghargai } \\
\text { batas personal pasien }\end{array}$ & $\begin{array}{l}\text { - Tidak menunjukkan } \\
\text { respon empati } \\
\text { - Tidak menghargai } \\
\text { pasien }\end{array}$ \\
\hline
\end{tabular}

Nilai rata-rata :

Saran perbaikan :

\section{Nilai Content Validity Index rubrik NCEx}

Berdasarkan penghitungan nilai CVI, seluruh domain beserta deskriptornya dianggap esensial dengan nilai CVI $=1$ (>0.99) oleh seluruh expert, sehingga domain dan deskriptornya merupakan aspek-aspek yang penting untuk dinilai dalam rubrik NCEx, seperti yang dapat dilihat pada Tabel 4 .

Tabel 4. Nilai CVR untuk masing-masing domain dalam lembar NCEX beserta deskriptornya

\begin{tabular}{llc}
\hline & Domain beserta deskriptornya & Nilai CVR \\
Pengkajian fokus data & Orientasi dan persiapan & 1 \\
& Pengkajian masalah utama & 1 \\
& Penentuan pola fungsi Gordon & 1 \\
& Interview data pelengkap & 1 \\
\hline Pengkajian fokus & Persiapan & 1 \\
pemeriksaan fisik & Sistematika dan fokus pemeriksaan & 1 \\
& Teknik pemeriksaan & 1 \\
\hline Perumusan diagnosa & Kemampuan interpretasi dan pemahaman ilmu biomedik & 1 \\
keperawatan & Pemilihan diagnosa dan pengelompokan data & 1 \\
& Format penulisan diagnosa & 1 \\
\hline Perencanaan perawatan & Penetapan tujuan & 1 \\
& Rencana tindakan & 1 \\
\hline Komunikasi dan hubungan & Komunikasi verbal & 1 \\
interpersonal & Komunikasi non verbal & 1 \\
\hline Profesionalisme & Penerapan nilai profesional & 1 \\
\hline
\end{tabular}




\section{Persepsi mahasiswa dan penguji}

Kuisioner dibagikan kepada 10 orang responden mahasiswa dan 6 orang rater/penguji yang melakukan penilaian dengan menggunakan rubrik NCEx. Kuisioner dinilai menggunakan skala likert dengan pilihan jawaban SS: sangat setuju, S: setuju, KS: kurang setuju, TD: tidak setuju dan STS: sangat tidak setuju. Kuisioner ini menilai apakah rubrik NCex mudah digunakan dan memiliki dampak terhadap pembelajaran. Respon mahasiswa dan penguji terhadap rubrik NCEx tertera pada tabel 5. Sebagian besar mahasiswa sangat setuju bahwa rubrik NCEx mudah dipahami dan sesuai dengan kompetensi perawat, mudah digunakan dan dapat diaplikasikan pada berbagai kondisi pasien. Respon yang sama juga ditunjukkan oleh para penguji/ rater. Bahwa sebagian besar dari mereka sangat setuju bahwa rubrik NCEx mudah digunakan dan diterapkan dalam praktik mereka sehari-hari.

Sebagian besar mahasiswa juga sangat setuju dan setuju bahwa proses NCEx memiliki dampak positif terhadap kemampuan mereka dalam merawat pasien. Disamping itu, feedback yang diberikan oleh penguji/penilai membuat performa mereka dalam merawat pasien menjadi lebih baik. Dalam hal pemberian feedback, penguji juga sangat setuju bahwa feedback yang mereka berikan memudahkan mahasiswa dalam memperbaiki performa dan memotivasi mereka serta meningkatkan performa dalam merawat pasien.

Tabel 5. Persepsi penguji dan mahasiswa mengenai kemudahan rubrik NCEx untuk digunakan sebagai instrument penilaian

\begin{tabular}{lcccc} 
& Sangat setuju & Setuju & Sangat setuju & Setuju \\
\cline { 2 - 5 } & Mahasiswa & Mahasiswa & Penguji & Penguji \\
\hline Applicability instrument & & & & \\
- Rubrik mudah dipahami & $100 \%$ & 0 & $67 \%$ & $33 \%$ \\
- Penilaian mudah dilakukan & $70 \%$ & $30 \%$ & $83 \%$ & $17 \%$ \\
- Rubrik mudah diterapkan pada pasien & $10 \%$ & $90 \%$ & $67 \%$ & $33 \%$ \\
\hline $\begin{array}{l}\text { Educational impact } \\
\text { - Feedback meningkatkan motivasi }\end{array}$ & $80 \%$ & $20 \%$ & $83 \%$ & $17 \%$ \\
- Feedback memperbaiki performa & $80 \%$ & $20 \%$ & $67 \%$ & $33 \%$ \\
- Deskriptor menggambarkan target & $70 \%$ & $30 \%$ & $67 \%$ & $33 \%$ \\
$\begin{array}{l}\text { pencapaian } \\
\text { - Mini CEx membantu menjalankan }\end{array}$ & $20 \%$ & $80 \%$ & $67 \%$ & $33 \%$ \\
- Meran sebagai perawat & & & & \\
$\quad$ berikutnya CEx berdampak terhadap performa & $70 \%$ & $30 \%$ & $67 \%$ & $33 \%$ \\
- Mini CEx mempengaruhi interaksi & $90 \%$ & $10 \%$ & $83 \%$ & $17 \%$ \\
$\quad$ dengan pasien & & & & \\
\hline
\end{tabular}

Sebuah instrumen dikatakan memiliki content validity yang baik jika terdapat kesesuaian antara konten yang dinilai dengan domain yang penting untuk diukur, tujuan dalam kurikulum dan standar nasional yang ditetapkan. ${ }^{19}$ Secara konten, rubrik NCEx dinilai valid oleh ke tujuh expert. Ini terlihat dari nilai CVR di seluruh domain dan deskriptor yang mencapai angka 1 , yang berarti bahwa domain yang terdapat dalam rubrik NCEx secara konten sudah merepresentasikan aspek-aspek penting yang harus dinilai dari kompetensi keperawatan. ${ }^{18}$ Untuk menjamin rubrik ini valid secara konten, proses pengembangan dimulai dengan merumuskan blueprint yang mampu meng-cover domain penting dalam kompetensi klinis keperawatan. Domain tersebut terdapat di standar kompetensi perawat di beberapa negara yang mewakili beberapa benua, dari penelitian survey kepada perawat di klinis. Setelah domain ditetapkan kemudian menetapkan deskriptor berdasarkan literatur fundamental 
keperawatan yang secara khusus dan mendalam membahas mengenai domain dalam kompetensi perawat secara lebih komprehensif dan dilanjutkan dengan proses review oleh expert. ${ }^{20}$

Berdasarkan hasil review oleh expert, disepakati 7 domain yang dinilai dalam rubrik NCEx, masingmasing domain terdiri dari beberapa item (tabel 8) dan masing-masing item memiliki deskriptor (lampiran 1) untuk menentukan skala nilai 0 berarti di bawah harapan, 1 sesuai harapan dan 2 di atas harapan. Rubrik yang menilai kompetensi klinis keperawatan ini bukanlah yang pertama dikembangkan, sebelumnya terdapat beberapa rubrik yang hampir serupa. Rubrik tersebut adalah Lasaster Clinical Judgement Rubric (LCJR) yang menilai kemampuan melakukan pengkajian dan pembuatan keputusan klinis. ${ }^{21}$ Rubrik yang berikutnya adalah Clinical Reasoning Grading Rubric yang menilai kemampuan membuat keputusan klinis. Rubrik NCEx yang dikembangkan dalam penelitian ini secara konten memiliki kekhususan karena rubrik ini berfokus untuk menilai performa mahasiswa dalam hal kemampuan mengkaji data subjektif pasien, pemeriksaan fisik, penentuan diagnosa dan perencanaan tindakan dengan tanpa mengabaikan unsur penilaian terhadap profesionalisme, dan kemampuan berkomunikasi.

Dalam proses review expert, beberapa expert menilai jika dibanding instrumen NCEx sebelumnya, hilangnya unsur tindakan kepada pasien merupakan salah satu kekurangan dari rubrik NCEx yang dikembangkan dalam penelitian. Secara teori kompetensi perawat seharusnya mencakup domain-domain penting dalam proses keperawatan yang meliputi pengkajian, penetapan diagnosa, penetapan perencanaan, pemberian tindakan pada pasien, evaluasi dan pendokumentasian. ${ }^{22}$ Namun, meski kurang komprehensif, secara fisibilitas, rubrik NCEx ini lebih mudah diterapkan karena membutuhkan waktu yang lebih singkat dalam prosesnya dan lebih fokus terhadap kemampuan spesifik mahasiswa (pengkajian, pemeriksaan fisik, penetapan diagnosa dan perencanaan keperawatan). Selain itu, rubrik NCEX ini bertujuan menilai domain kompetensi perawat secara general, sehingga untuk menilai tindakan keperawatan diperlukan instrumen tersendiri yang lebih rigid karena tindakan sifatnya procedural. Beberapa masukan untuk penyempurnaan lebih lanjut dari rubrik ini, sebaiknya dibuat rubrik yang menilai kompetensi keperawatan secara lebih komprehensif namun tetap fisibel dan praktis untuk diterapkan. Sebagai alternatif dapat dilampirkan instrument penilaian tindakan secara tersendiri, sebagai pelengkap instrument NCEX.

NCEx dinilai mudah diaplikasikan dan memiliki dampak positif terhadap pembelajaran. Hampir 100 persen mahasiswa dan penguji setuju dan sangat setuju bahwa rubrik NCEx sangat membantu proses pembelajaran di klinik dan mudah diterapkan di seting klinik. Hal ini serupa dengan penelitian yang dilakukan oleh Hoseini et al tahun 2013 yang meneliti persepsi mahasiswa keperawatan dan kebidanan terhadap instrumen penilaian NCEx dan penelitian yang dilakukan Weller et al tahun 2009. Unsur terpenting dalam penilaian yang memiliki dampak terhadap proses pembelajaran adalah adanya unsur feedback dari penilai. Pada rubrik NCEx ini, mahasiswa dan penguji setuju dan sangat setuju kalau feedback dalam proses NCEx yang diperkuat dengan adanya deskriptor membantu untuk memperbaiki performa berikutnya. Namun meski penguji setuju dan sangat setuju bahwa rubrik ini mudah digunakan, proses sosialisasi dan perbaikan tetap perlu dilakukan untuk meningkatkan kualitas penilaian.

\section{KESIMPULAN}

Berdasar hasil penelitian yang telah dipaparkan pada bagian sebelumnya, dapat ditarik tiga butir kesimpulan. Yang pertama, domain dalam NCEx berbeda dengan domain yang dinilai NCEx adalah: pengkajian fokus data subjektif, pengkajian fokus pemeriksaan fisik, Perumusan diagnosa keperawatan, Perencanaan perawatan, Komunikasi dan hubungan interpersonal, Profesionalisme. Berikutnya, content validity rubrik NCEx dinilai baik dengan skor CVR di seluruh domain, item domain dan dekriptor $=1$. Yang terakhir, rubrik NCEx dapat diaplikasikan di pembelajaran klinik dan memiliki dampak terhadap pembelajaran di klinik. 


\section{DAFTAR PUSTAKA}

1. Wu XV, Enskär K, Lee CCS, Wang W. A systematic review of clinical assessment for undergraduate nursing students. Nurse Education Today, 2015;35(2):347-59.

2. Carr SJ. Assessing clinical competency in medical senior house officers: how and why should we do it? Postgraduate Medical Journal, 2004;80(940):63-6.

3. Sargeant J, Macleod T, Sinclair D, Power M. How do physicians assess their family physician colleagues' performance? Creating a rubric to inform assessment and feedback. Journal of Continuing Education in the Health Professions, 2011;31(2):87-94.

4. Roghieh N, Fateme H, Hamid S, Hamid H. The effect of formative evaluation using "direct observation of procedural skills" (DOPS) method on the extent of learning practical skills among nursing students in the ICU. Iranian Journal of Nursing and Midwifery Research, 2013;18(4):290.

5. Lesa R, Dixon A. Physical assessment: implications for nurse educators and nursing practice. International Nursing Review, 2007;54(2):166-72.

6. Horwitz LI, Dombroski J, Murphy TE, Farnan JM, Johnson JK, Arora VM. Validation of a handoff assessment tool: The Handoff CEX. Journal of Clinical Nursing, 2013;22(9-10):1477-86.

7. Norcini JJ, Blank LL, Arnold GK, Kimball HR. The mini-CEX (clinical evaluation exercise): A preliminary investigation. Ann Inter Med, 1995;123:795-9.

8. Swanwick T, Chana N. Workplace assessment for licensing in general practice. British Journal of General Practice, 2005;55(515):461-7.

9. Weller JM, Jolly B, Misur MP, Merry AF, Jones A, Crossley JM et al. Mini-clinical evaluation exercise in anaesthesia training. British Journal of Anaesthesia, 2009; 102(5):633-41.

10. Fernando N, Cleland J, McKenzie H, Cassar K. Identifying the factors that determine feedback given to undergraduate medical students following formative mini-CEX assessments. Medical Education, 2008;42(1):89-95.

11. Bourgault AM, Mundy C, Joshua T. Comparison of audio vs. written feedback on clinical assignments of nursing students. Nursing Education Perspectives, 2013;34(1):43-6.
12. Cyr PR, Smith KA, Broyles IL, Holt CT. Developing, evaluating and validating a scoring rubric for written case reports. International Journal of Medical Education, 2014;5:18.

13. Hung HT, Chiu YCJ, Yeh HC. Multimodal assessment of and for learning: A theory-driven design rubric. British Journal of Educational Technology, 2013;44(3):400-9.

14. Rochford L, Borchert PS. Assessing higher level learning: Developing rubrics for case analysis. Journal of Education for Business, 2011;86(5):25865.

15. HolmboeES, Yepes M, Williams F, Huot SJ. Feedback and the mini clinical evaluation exercise. Journal of General Internal Medicine, 2004;19(5p2);558-61.

16. Glover PA. 'Feedback. I listened, reflected and utilized': Third year nursing students' perceptions and use of feedback in the clinical setting. International Journal of Nursing Practice, 2000;6(5):247-52.

17. Day T, Iles N, Griffiths P. Effect of performance feedback on tracheal suctioning knowledge and skills: randomized controlled trial. Journal of Advanced Nursing, 2009;65(7):1423-31.

18. Cohen RJ, Swerdlik ME, Phillips SM. Psychological testing and assessment: An introduction to tests and measurement. Mayfield Publishing Co.;1996.

19. Nitko AJ, Brookhart SM. Educational Assessment fo Students. Boston: Pearson Education; 2011.

20. Delgado-Rico E, Carretero-Dios H, Ruch W. Content validity evidences in test development: An applied perspective1. International Journal of Clinical and Health Psychology, 2012;12(3):449.

21. Lasater K. Clinical judgment development: Using simulation to create an assessment rubric. Journal of Nursing Education, 2007;46:496-503.

22. Wanda. An investigation of clinical assessment processes of student nurses in Jakarta, Indonesia [Doctoral dissertation], Australian Catholic University; 2007. 